\title{
Historical development of irrigated agriculture under the Malaprabha Project, Karnataka, India
}

\author{
Usha Aswathaiah* and Lakshman Nandagiri \\ Department of Applied Mechanics and Hydraulics, National Institute of Technology Karnataka, Surathkal 757 025, India
}

\begin{abstract}
The present study analyses the historical development of irrigated agriculture in the command area of the Malaprabha irrigation project located in a semi-arid region of Karnataka, India. Considering the historical period from 1965 to 2014 , spatio-temporal changes in irrigated area, cropping patterns, crop and irrigation water requirements using CROPWAT model and sources of irrigation water were characterized relative to the pre-project period at decadal time-step. Overall results indicate an increase in irrigated area, departure from the planned cropping pattern and a shift towards cultivation of water-intensive cash crops, canal releases not conforming to estimated irrigation water requirements and an increase in groundwaterbased irrigation in the command area of the project. The findings of this study can be used to formulate more effective management strategies to improve the efficiency of the project and promote sustainable development of natural resources.
\end{abstract}

Keywords: Command area, cropping patterns, groundwater, historical development, irrigated agriculture.

INDIA has made impressive strides in establishing major irrigation projects to ensure food security for millions of its people. As of 2013-14, the total gross irrigated area in the country was $95.7 \mathrm{M}$ ha (ref. 1), and the total storage capacity in 91 large reservoirs was 157.7 BCM (ref. 2). While the growth in irrigated agriculture has been quite significant since 1950 (ref. 3), questions have been raised as to whether water-use efficiencies and agricultural productivities in the command areas of these large projects have been optimal ${ }^{4}$. The issue of optimal irrigation performance assumes great significance since irrigated agriculture is the largest consumer (90\%) of freshwater resources in the country.

This issue is not confined to only Indian projects, as a large number of irrigation projects across the world are reported to be in a state of poor working performance ${ }^{5-7}$. Accordingly, several studies on performance evaluation of irrigated projects have been taken up. It has been reported that the major causes for reduction in perfor-

*For correspondence. (e-mail: ush.aswath07@gmail.com) mance are inefficient planning and resource management, untimely system operation and maintenance, lack of participatory planning and management in schemes proposed by government agencies, continued use of inefficient flood irrigation practices and gross violation of proposed cropping patterns and water utilization rules $^{6,8-12}$.

A few studies have assessed water-use efficiencies and agricultural productivity of major Indian irrigation projects ${ }^{10,11,13-17}$. However, these have focused on issues related to crop water requirements (CWRs) and irrigation water requirements (IWRs), growth of irrigated area and cropping patterns. Only a few studies have evaluated spatio-temporal changes in irrigated area, cropping patterns, water requirements and sources of irrigation water in the command areas over long periods following commissioning of major irrigation projects. Accordingly, the present study was taken up to analyse the historical development of irrigated agriculture in the Malaprabha irrigation project, which was commissioned in 1972 in a semi-arid region of Karnataka, India. The objective of the study was to assess the spatio-temporal changes in cropping-patterns, the extent of irrigation, water requirements of crops and the role of groundwater in providing irrigation water supplies over the period 1965-2014 in the command area of the project. The main focus of the study was to compute CWR and irrigation water IWR of crops grown in the command area using the CROPWAT model. The model is being successfully applied in Indian conditions ${ }^{18-23}$ and uses procedures suggested by Allen et al. ${ }^{24}$ to estimate CWR and IWR using data pertaining to climate, crops and soils.

\section{Malaprabha river basin}

Malaprabha river basin is a prominent tributary of River Krishna and flows towards the east in the northern part of Karnataka, India (Figure 1). The drainage area of the basin is $11,400 \mathrm{sq}$. $\mathrm{km}$ and consists of upper humid, central semi-arid and lower arid climatic zones. The basin receives average annual rainfall ranging between 450 and $700 \mathrm{~mm}$, mostly due to the southwest monsoon. The average air temperature ranges between $20^{\circ} \mathrm{C}$ and $32^{\circ} \mathrm{C}$. 

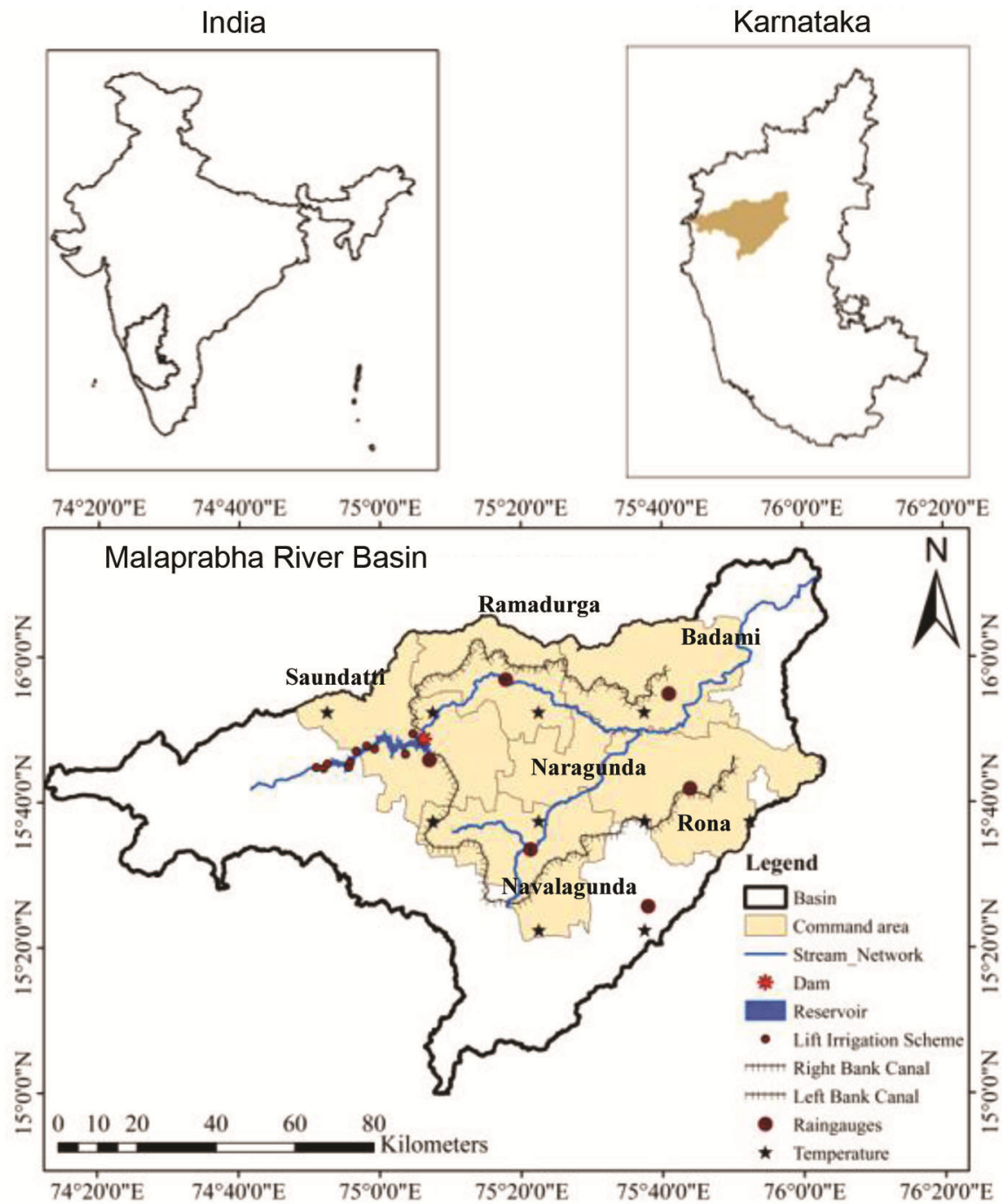

Figure 1. Location map of Malaprabha river basin showing the irrigation command area.

Table 1. Cropping pattern in the Malaprabha command area

\begin{tabular}{lcccc}
\hline Proposed cropping pattern & & \multicolumn{2}{c}{ Existing cropping pattern } \\
\cline { 1 - 2 } \cline { 5 - 5 } Crop & Kharif $(\%)$ & & Kharif $(\%)$ & Rabi $(\%)$ \\
\hline Paddy & - & & 100 & - \\
Jowar & 100 & & 60 & 40 \\
Maize & 100 & & 60 & 40 \\
Wheat & - & & - & 100 \\
Green gram & - & & 60 & 40 \\
Bengal gram & - & & 60 & 40 \\
Groundnut & 100 & & 100 & - \\
Sunflower & - & & - & 100 \\
Cotton & - & & 60 & 40 \\
Sugarcane & - & & 100 & \\
\hline
\end{tabular}

Black cotton soil and red loamy soil are predominant in the river basin. Agriculture is the main occupation of about $85 \%$ of the population in the region.

\section{Malaprabha irrigation project}

Malaprabha irrigation project was commissioned in 1972 to provide irrigation facility to several talukas of the basin which have suffered from severe drought and water scarcity in the past ${ }^{25}$. A dam was constructed at Navilutheertha $\left(15^{\circ} 49^{\prime} \mathrm{N}\right.$ lat. and $75^{\circ} 6^{\prime} \mathrm{E}$ long.), in Saundatti taluk, Belgaum district, Karnataka (Figure 1) having a catchment area of $2564 \mathrm{sq}$. $\mathrm{km}$. The dam has a gross storage capacity of $1070 \mathrm{MCM}$ and live storage capacity of $830 \mathrm{MCM}$, and average annual inflow for the period 1973-2015 was 1044 MCM. Black cotton soil covers major portions of the irrigated area under the reservoir command area. The project was planned to create a total irrigation potential of 196,132 ha in Malaprabha command area through two main canals, namely Malaprabha Right Bank Canal (MRBC-121,392 ha) and Malaprabha Left Bank Canal (MLBC-47,769 ha), and 11 foreshore lift irrigation schemes (LIS - 26,971 ha) ${ }^{26}$. 
Table 2. Datasets procured for the present study

\begin{tabular}{|c|c|c|c|}
\hline Data type & Period & Resolution & Source \\
\hline $\begin{array}{l}\text { Cultivated area, irrigated area, crop } \\
\text { area and sources of irrigation in } \\
\text { Malaprabha command area }\end{array}$ & $1965-2014$ & $\begin{array}{l}\text { Taluk-wise } \\
\text { decadal }\end{array}$ & $\begin{array}{l}\text { District at a Glance reports, Government of Karnataka, and published } \\
\text { values from refs } 25 \text { and } 31 \text { doctoral thesis from the Department of } \\
\text { Agriculture and Geography, University of Dharwad, Karnataka }\end{array}$ \\
\hline Canal water releases & $1972-2014$ & Daily & $\begin{array}{l}\text { Executive Engineer, Malaprabha Left Bank Canal Construction } \\
\text { Department, Division II, Navilutheertha, Belgaum }\end{array}$ \\
\hline Maximum and minimum temperatures & $1965-2014$ & $\begin{array}{l}\text { Daily } \\
0.25^{\circ} \times 0.25^{\circ}\end{array}$ & $\begin{array}{l}\text { NASA Earth Exchange Global Daily Downscaled Projections - NEX- } \\
\text { GDDP (ACCESS1-0 model) }\end{array}$ \\
\hline
\end{tabular}

The Malaprabha command area spreads over nine talukas of Belgaum, Bagalkot, Dharwad and Gadag districts in Karnataka. However, only six talukas are included in the present analysis (Figure 1), as the remaining three contribute less than $4 \%$ of their irrigated area. The talukas considered for this the study are Saundatti, Ramadurga, Naragunda, Rona, Navalagunda and Badami, with total irrigation potential of 183,393 ha under the project $^{26,27}$.

The Malaprabha irrigation project is protective in nature and proposed for the irrigation of majorly dry crops in the command area (Table 1). However, currently more than 15 different types of crops are grown in the command area which may be classified as cereals, pulses, oilseeds, cash crops and other food crops, including more water-intensive crops. The availability of additional surface and groundwater encouraged the farmers to start cultivating more water-intensive crops such as sugarcane, paddy and tobacco ${ }^{28-30}$. This violation in cropping pattern and adoption of flood irrigation has resulted in several water-related problems in the basin, such as water shortage for the tail-end users, lowering of groundwater levels under irrigated areas ${ }^{30}$ and leaching problems in regions close to the reservoir ${ }^{31}$.

\section{Materials and methods}

A taluk is considered as the spatial unit for analysis in the present study. Accordingly, taluk-wise relevant data for the historical period extending over 50 years (1965-2014) were procured from various published government reports and a doctoral thesis (Table 2$)^{25,31}$. Daily rainfall and temperature data were obtained for the locations in and around Malaprabha command area (Figure 1) for the period of analysis ${ }^{32-34}$. However, for highlighting temporal changes in the variables considered over a decadal time-step, results are presented separately for the years 1965-66, 1975-76, 1985-86, 1993-94, 2003-04 and 2013-14. While 1965-66 represents the pre-dam condition, the other years are representative of evolving conditions after commissioning of the Malaprabha project in 1972.

\section{CROPWAT 8.0}

CROPWAT is a decision support system developed by the Land and Water Development Division of the United Nations Food and Agricultural Organization ${ }^{35}$, Rome, for planning and management of irrigation activities. The model is envisioned as a practical tool to carry out standard calculations for reference crop evapotranspiration $\left(\mathrm{ET}_{0}\right)$, effective rainfall $\left(P_{\mathrm{eff}}\right), \mathrm{CWR}$ and IWR and more explicitly for the design and management of irrigation schemes. It is capable of planning irrigation schedules under changing water supply conditions and assessing crop production under rainfed or deficit irrigation circumstances.

\section{Cropping pattern}

The cropping pattern in the Malaprabha command area has evolved over time in response to the irrigation project, socio-economic development in the area and establishment of agriculture processing industries, etc. ${ }^{25}$. The project was envisaged to provide irrigation for less water-intensive crops in the kharif season only ${ }^{26}$. Table 1 shows the proposed cropping pattern and that existing in 2013-14 in the command area, from which significant differences are evident.

Application of CROPWAT also requires specification of season-wise cropping pattern in the command area. However, this is a complex task on account of the heterogeneity in crops grown and dynamics involved in the present cropping patterns. Thus, for the sake of simplicity, logical approximations were made regarding cropping pattern in the basin and the same pattern was assumed to be valid for all six decades. As jowar, maize, pulses and cotton are grown in both kharif and rabi seasons, a share of $60 \%$ and $40 \%$ of their sown areas was distributed to the two seasons respectively. The planting date for the two seasons was selected as 15 June and 15 October respectively, for all the crops (following command Area Development Authority information $)^{27}$. 


\section{Reference crop evapotranspiration}

Since historical climatic data required for estimating reference crop evapotranspiration by the preferred Penman-Montieth method were unavailable, the temperature-based Hargreaves method (eq. (1) ${ }^{24}$ was used instead. Daily temperature values were converted to monthly averages and used to compute monthly $\mathrm{ET}_{0}$ values.

$$
\mathrm{ET}_{0}=0.0023(\bar{T}+17.8)\left(T_{\max }-T_{\min }\right)^{0.5} \times R_{\mathrm{a}},
$$

where $\mathrm{ET}_{0}$ is the reference crop evapotranspiration $(\mathrm{mm} /$ day); $T_{\max }, T_{\min }$ and $\bar{T}$ are the maximum, minimum and mean monthly temperature $\left({ }^{\circ} \mathrm{C}\right)$ respectively, and $R_{\mathrm{a}}$ is the extra-terrestrial radiation $\left(\mathrm{MJ} \mathrm{m}^{-2} \mathrm{~d}^{-1}\right)$ calculated according to Allen et $a l^{24}$. The computed monthly $\mathrm{ET}_{0}$ values were provided as input to the CROPWAT model.

\section{Crop evapotranspiration and crop coefficients}

CROPWAT computes crop evapotranspiration values $\left(E_{c}\right)$ which represent CWR using the single-crop coefficient $\left(K_{\mathrm{c}}\right)$ approach as

$$
\mathrm{CWR}=\mathrm{ET}_{\mathrm{c}}=\mathrm{ET}_{0} \times K_{\mathrm{c}} .
$$

Subsequently, IWR was computed as

$$
\mathrm{IWR}=\mathrm{CWR}-P_{\text {eff }} .
$$

Gross IWR was obtained by assuming irrigation efficiency of $50 \%$. Effective precipitation $\left(P_{\text {eff }}\right)$ was calculated with CROPWAT using the USDA-Soil Conservation Service approach

$$
\begin{gathered}
P_{\text {eff }}=\frac{P \times(125-0.2 P)}{125} \text { for } P \leq 250 \mathrm{~mm}, \\
P_{\text {eff }}=125+0.1 \mathrm{P}, \quad \text { for } P>250 \mathrm{~mm},
\end{gathered}
$$

where $P$ is the total rainfall (mm).

Growth stage-wise $K_{\mathrm{c}}$ values for each crop are needed to implement eq. (2). Curves showing temporal variation of $K_{\mathrm{c}}$ over the growing season for each of the selected crops were derived using of duration of initial $\left(L_{\text {ini }}\right)$, development $\left(L_{\mathrm{dev}}\right)$, mid-season $\left(L_{\mathrm{mid}}\right)$ and late-season $\left(L_{\text {late }}\right)$ values and the corresponding values of crop coefficients for initial $\left(K_{c_{\text {ini }}}\right)$, mid-season $\left(K_{c_{\text {mid }}}\right)$ and harvest $\left(K_{c_{\text {end }}}\right)$. Standard values of durations and crop coefficients (Table 3) and data on crop characteristics such as yield response, crop height, minimum and maximum rooting depths were obtained from the literature ${ }^{24,36,37}$.

\section{Results and discussion}

\section{Growth of irrigated agriculture}

Figure 2 depicts changes in the net cultivated and irrigated areas along with average rainfall for the past six decades over the Malaprabha command area. Although not much change was observed in the net cultivated area, a rapid growth of irrigated agriculture can be noticed in the region since the commissioning of the irrigation project during 1972. The irrigation intensity (ratio of net irrigated area to cultivated area) increased from $0.76 \%$ during $1965-66$ to $56.82 \%$ during $2013-14$.

It is interesting to note that the planned potential has not been achieved even after 33 years (2003-04) of commissioning of the project. In fact, the net irrigated area decreased in 2003-04 in comparison to 1993-94, when it registered a value of 147,855 ha. This decrease could be attributed to decrease in rainfall $(369 \mathrm{~mm})$ during 2003-04 and consequent reduction of inflows into the Malaprabha reservoir. As on 2013-14, the net irrigated

\begin{tabular}{|c|c|c|c|c|c|c|c|c|}
\hline \multirow[b]{2}{*}{ Crop } & \multicolumn{3}{|c|}{$K_{\mathrm{c}}$ value } & \multicolumn{5}{|c|}{ Length of crop stages (days) } \\
\hline & $K_{\mathrm{c}_{\mathrm{ini}}}$ & $K_{\mathrm{c}_{\text {mid }}}$ & $K_{\mathrm{c}_{\mathrm{end}}}$ & $L_{\mathrm{ini}}$ & $L_{\mathrm{dev}}$ & $L_{\text {mid }}$ & $L_{\text {late }}$ & Total \\
\hline Paddy & 1.05 & 1.2 & 0.7 & 30 & 30 & 60 & 30 & 150 \\
\hline Jowar & 0.7 & 1.15 & 1.05 & 20 & 35 & 40 & 30 & 125 \\
\hline Maize & 0.7 & 1.15 & 1.05 & 20 & 35 & 40 & 30 & 125 \\
\hline Wheat & 0.3 & 1.15 & 1.4 & 15 & 25 & 50 & 30 & 120 \\
\hline Green gram & 0.4 & 1.15 & 0.35 & 20 & 20 & 50 & 20 & 110 \\
\hline Bengal gram & 0.4 & 1.15 & 0.35 & 20 & 20 & 50 & 20 & 110 \\
\hline Groundnut & 0.4 & 1.15 & 0.6 & 35 & 35 & 35 & 35 & 140 \\
\hline Sunflower & 0.35 & 1.15 & 0.35 & 25 & 35 & 45 & 25 & 130 \\
\hline Cotton & 0.35 & 1.2 & 0.7 & 30 & 50 & 60 & 55 & 195 \\
\hline Sugarcane & 0.4 & 1.25 & 0.75 & 15 & 70 & 220 & 140 & 445 \\
\hline
\end{tabular}
area was 240,039 ha, which is significantly higher than the planned irrigation potential of 183,393 ha for the area under consideration. This surplus irrigated area is an

Table 3. Crop coefficients $\left(K_{\mathrm{c}}\right)$ and length of growth stages of crops

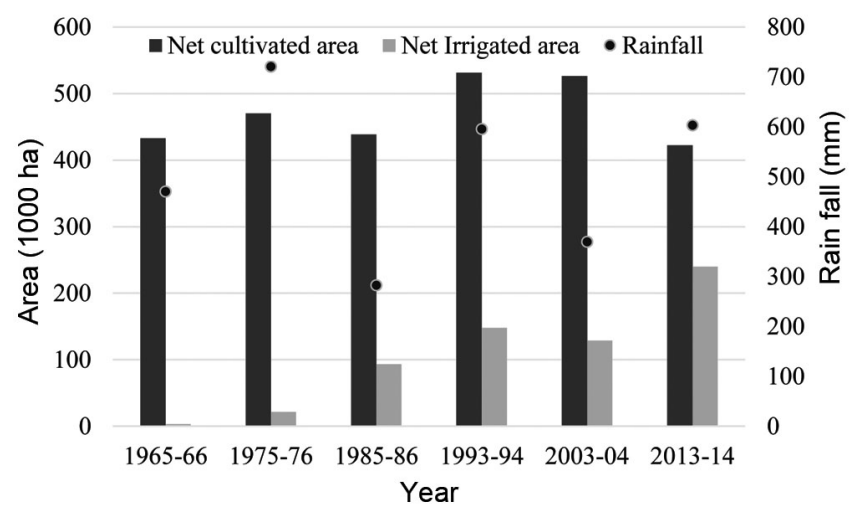

Figure 2. Growth of net cultivated and irrigated areas in the Malaprabha command area. (Source: Data compiled from refs 25 and 31 and district at a glance reports of Bagalkot, Belgaum, Dharwad and Gadag.) 
outcome of increased groundwater-based irrigation in the region.

\section{Sources of irrigation water supply}

The main sources of irrigation water in the Malaprabha command area are canals, tanks, wells and other sources which consist of mainly lift irrigation (Figure 3 ). It can be noticed from Figure 3 that tanks and dug/open wells catered to $20 \%$ and $70 \%$ of the irrigated area respectively, during 1965-66 which represents the pre-project condition.

The irrigated area under canal supply showed an abrupt increase with the commissioning of the project and served 9169 ha in 1975-76. It continued to be the major source of irrigation till 1993-94 and its maximum contribution (61\%) was in 1985-86. However, by 2013-14 the share of the canal reduced to $41 \%$, although it catered to the largest extent of irrigated area (98,339 ha) during the period of analysis.

The next important source of irrigation is groundwater extracted through bore and dug wells. With falling groundwater levels, tube wells are gradually replacing dug/open wells. Despite introduction of canal water supplies in 1972, the irrigated area under groundwater supplies has registered a steady and steep increase in the last 40 years. It is interesting to note that during 2003-04 and 2013-14, groundwater replaced canal supplies as the highest contributor ( $46 \%$ and $48 \%$ respectively) to irrigated agriculture in the region.

Other sources of irrigation include minor transfers from small barrages constructed across the river to fields and major transfers through lift irrigation from the reservoir. Also, there is illegal pumping of water from the canals, which is supplied to the fields through pipelines. The irrigated area under this source increased from 306 ha in $1965-66$ to 26,794 ha in 2013-14. Tanks were important sources of irrigation prior to dam construction. Though their contribution has decreased from 648 ha in 1965-66 to 163 ha in 2013-14, they continue to play a significant role in irrigation supply in highland regions where the canal network is not present.

From these results it can be seen that as of 2013-14 the total irrigated area in the command under canal (41\%) and lift schemes (11\%) was 125,133 ha, whereas the planned irrigation potential was 183,393 ha (ref. 26). The fact that even after 43 years of commissioning the project has not been able to meet the planned objective could be attributed to a variety of reasons, such as violation of planned cropping pattern, flood irrigation practice, non-delivery of water to tail-enders, poor performance of canal and associated structures, and increasing conveyance losses. It is probably for these reasons that farmers have shifted to groundwater as a more reliable and readily available source of irrigation water supply in the command area. This has resulted in an increase in irrigated area, especially in areas not served by the canal system and also in tail-end regions of the canal network.

\section{Spatio-temporal variation of irrigated agriculture}

Figure 4 displays the taluk-wise spatio-temporal development of the irrigated area (\%) under different sources across the Malaprabha command area from 1965-66 to 2013-14. It is evident from Figure $4 a$ that prior to the commissioning of the irrigation project during 1965-66, groundwater wells and tanks were the major source of irrigation throughout the region. Ramadurga taluk to the northwest had the largest number of tanks in the past ${ }^{25}$, and area under this irrigation source was $35 \%$ of the total irrigated area. During this period, Rona taluk was completely underground water irrigation, mainly through open and dug wells. Saundatti with an irrigated area of 1076 ha had supplies from groundwater, tanks and other sources, whereas Naragund taluk had the least irrigated area of 170 ha with groundwater supplies. Details for Navalgund taluk were unavailable for this period.

Figure $4 b$ clearly represents the advent of canal irrigation during 1975-76 to taluks close to the reservoir (Soundatti, Ramadurga, Navalgund and Naragund). On the other hand, Rona and Badami taluks lack canal water as construction of canal structures was still in progress. It can also be observed that the taluks that experienced a rapid increase in canal irrigation have naturally registered a decrease in the area under tank and well irrigation.

During 1985-86 further extension of canal irrigation took place and canal water supplies reached up to Rona taluk (Figure $4 c$ ). Also, the total area under lift irrigation and others (19\%) was becoming significant at this stage, which was the main source of irrigation at the tail-end regions of command area such as Badami taluk (59\%).

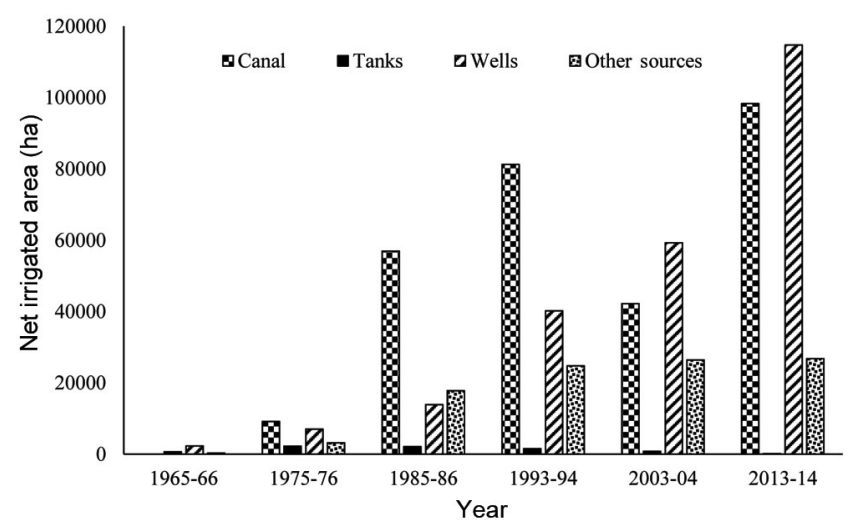

Figure 3. Source-wise irrigated area in the Malaprabha river command area. (Source: Data compiled from refs 25 and 31 and district at a glance reports of Bagalkot, Belgaum, Dharwad and Gadag, Government of Karnataka.) 


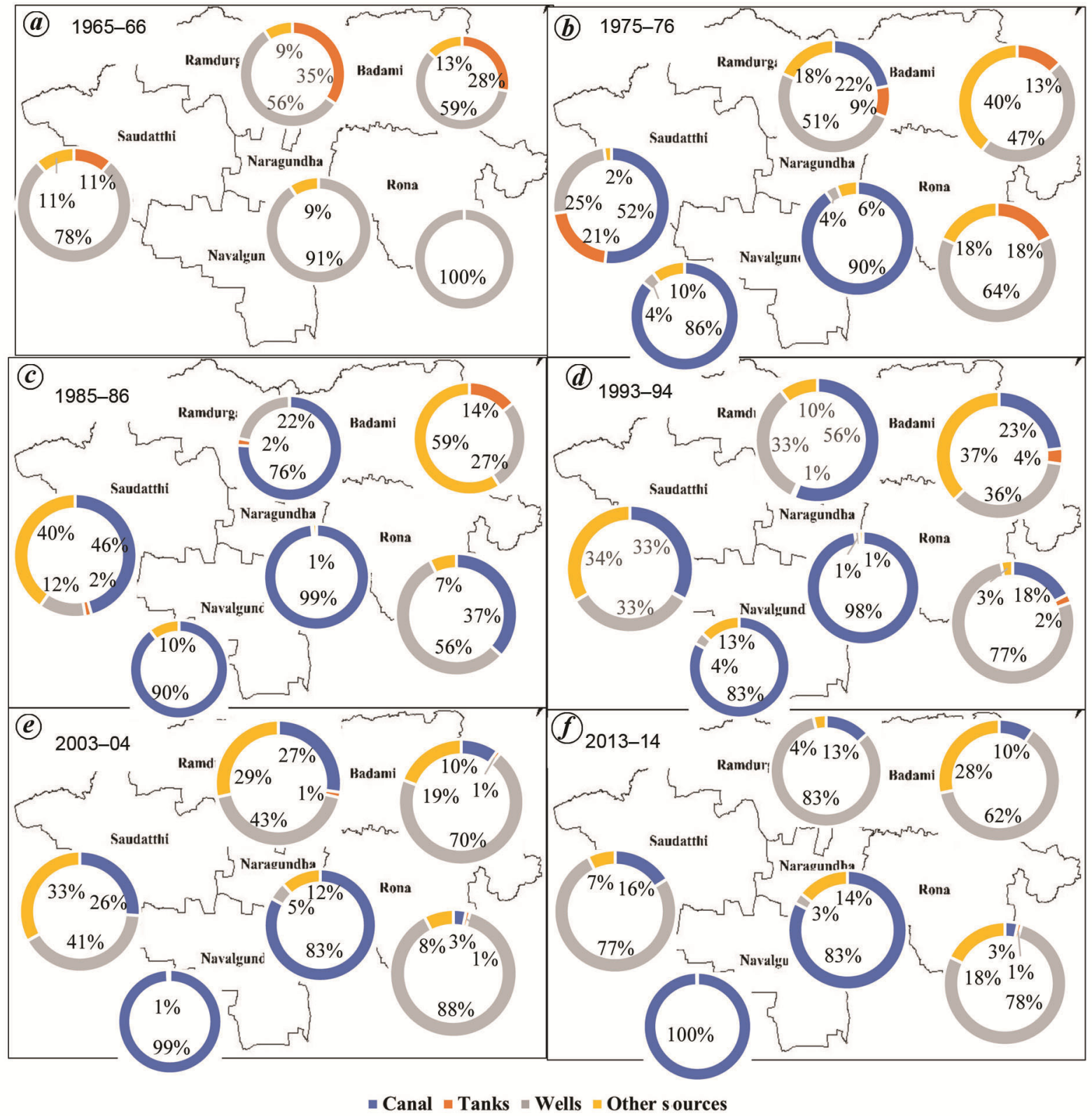

Figure 4. $\boldsymbol{a}-\boldsymbol{f}$, Spatio-temporal development of source-wise irrigated area in the Malaprabha command area. (Source: Data compiled from refs 25 and 31 and district at a glance reports of Bagalkot, Belgaum, Dharwad and Gadag, Government of Karnataka.)

Also, reservoir water was supplied to the upstream command area in Saundatti taluk through lift irrigation. In 1993-94, canals and associated works were fully developed and canal water was supplied to all taluks of the command area (Figure $4 d$ ). However, by this time a major shift was observed in the source of irrigation as a result of a change in cropping pattern (growing highly water-intensive crops instead of the proposed dry crops), flood irrigation, illegal withdrawal of water from canals to fields, and also decrease in canal efficiency due to poor operation and maintenance ${ }^{30}$. All these factors resulted in inadequate supply of canal water to tail-end regions. Therefore, exploitation of groundwater sources for irriga- tion increased in the command area, especially in Rona (77\%) and Badami (36\%) taluks. A decrease in total canal $(61-54 \%)$ and lift irrigated $(19-16 \%)$ areas was accompanied by an increase in well-irrigated areas (14$27 \%$ ) during this period.

The period 2003-04 is one of the deficit (drought) years in the river basin with decreased annual rainfall of $369 \mathrm{~mm}$ in the command area. The amount of total canal irrigated area decreased to $32 \%$, and consequently groundwater irrigated area increased up to $46 \%$ in the command area (Figure 3). The decreased canal and significantly increased groundwater irrigated areas were observed in all the taluks, except Navalagunda (99\%) and 
Naragunda (83\%) during this period (Figure $4 e$ ). During 2013-14, the command area received higher rainfall $(603 \mathrm{~mm})$ and total irrigated area increased to 240,039 ha (Figure 3). However, the contribution of canal and lift irrigation together $(125,133 \mathrm{ha})$ was still less than the proposed irrigation potential $(183,393 \mathrm{ha})$ of the project. On the other hand, groundwater was the dominant source of irrigation in all the taluks of command area, except Navalgunda and Naragunda where canal irrigation was significant (Figure $4 f$ ).

Overall, the efficiency of Malaprabha irrigation project appears to have decreased in the last two decades considered in this analysis and only the taluks close to the reservoir seem to be getting maximum benefit of the project. Taluks located further away are greatly dependent on groundwater and lift irrigation sources for crop cultivation.

\section{Cropping pattern}

Figure 5 shows the changes in area under major crop classes cultivated in the Malaprabha command area. The cropping intensity (per cent ratio of gross cropped area to net cropped area) in the region has increased from $125 \%$ to $165 \%$ in the past five decades, indicating increase in the number of crops grown from the same field. Cereals share the maximum amount $(>40 \%)$ of cropped area among all other classes, followed by pulses $(25 \%)$. The production of pulses has increased in the last two decades of the analysis. Though not significant, the crop area under other food crops which include mainly vegetables, has increased continuously from $1 \%$ to $8 \%$ since $1965-66$.

The cash crops which mainly consist of cotton and sugarcane decreased till 2003-04, but increased in 201314. As of 2013-14, the percentage area under various crops was as follows: cereals -40 , pulses -25 , cash crops -14 , oilseeds -13 and other crops -8 . More than

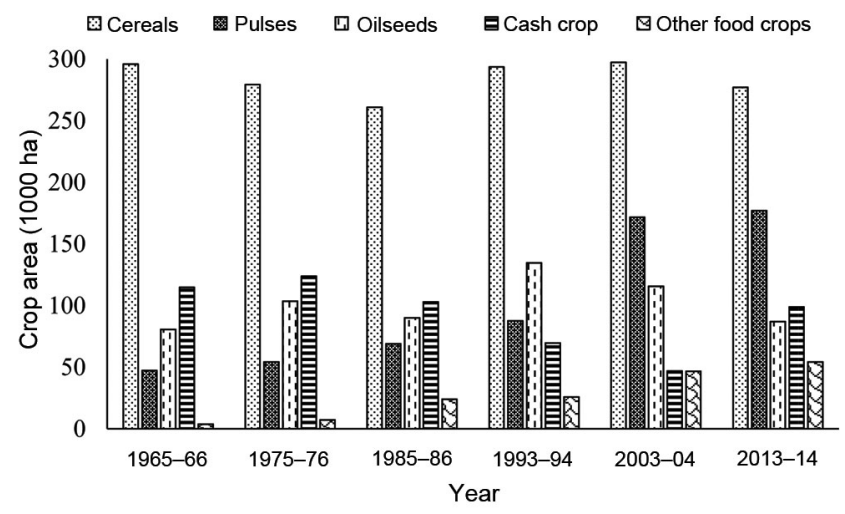

Figure 5. Changes in area under major crop classes in the Malaprabha command area. (Source: Data compiled from refs 25 and 31 and district at a glance reports of Bagalkot, Belgaum, Dharwad and Gadag, Government of Karnataka.)
15 types of crops are grown in the Malaprabha command area. Figure 6 represents the cultivated area of some important crops under each major crop category. Although the overall increase in cropping area over the six decades is $28 \%$, there exist large deviations among the type of crops and their extent of growth in the region during the period of analysis. The major shifts observed are decrease in area under cotton (40\%) and increase in area under sugarcane (286\%) from 1965 to 2014, which is an annual crop consuming around $2500 \mathrm{~mm}$ of water. The area under paddy cultivation also increased up to $60 \%$ by 1993-94 and decreased thereafter. Also, in the oilseeds category, decrease in groundnut and increase in comparatively water-intensive sunflower crop was noted. Overall, the major deviations observed in the cropping pattern were shift from traditional crops to high-yielding, waterintensive crops, and increase in commercial and cash crops instead of the proposed dry crops.

\section{Historical crop and irrigation water requirements}

CWR and IWR for the major crops grown in the study area were estimated using the CROPWAT 8.0 model for the proposed and existing cropping patterns for the historical period of analysis. The calculated basin average monthly $\mathrm{ET}_{0}$ values using the Hargreaves method were incorporated into the model. Considering rainfall records for six rain gauges (Figure 1), Thiessen average rainfall over the Malaprabha command area for the historical period was also given as input to the model to estimate $P_{\text {eff. }}$ The cropping pattern shown in Table 1 and crop coefficients shown in Table 3 were provided as inputs to CROPWAT.

Figure 7 shows the variation of annual $\mathrm{ET}_{0}, P_{\text {eff }}$ and rainfall over the command area for the past six decades. The average annual $\mathrm{ET}_{0}$ in the command area was $1683 \mathrm{~mm}$ and average $P_{\text {eff }}$ was about $84 \%$ of the rainfall in the region with maximum $P_{\text {eff }}$ occurring in 1993-94 $(93 \%)$ and minimum in 1975-76 (78\%). Figures 8 and 9 show variations of estimated CWR and IWR for the proposed and existing cropping patterns over the period of analysis. The average CWR of the existing cropping pattern was around $170 \%$ higher than the proposed cropping pattern (Figure 8). Also, CWR of the proposed cropping pattern remained more or less constant with an average value of $1264 \mathrm{MCM}-\mathrm{CWR}$ for the existing cropping pattern increased from 3189 to $4024 \mathrm{MCM}(26 \%)$ between 1965-66 and 2013-14.

IWR for the proposed cropping pattern was estimated considering $100 \%$ irrigation in the kharif season for the entire irrigable command area envisaged originally ${ }^{27}$ has never practiced in the study area. However, IWR for the existing cropping pattern was estimated only for the actual area irrigated during the respective years. Since the proposed cropping pattern is assumed to be implemented 


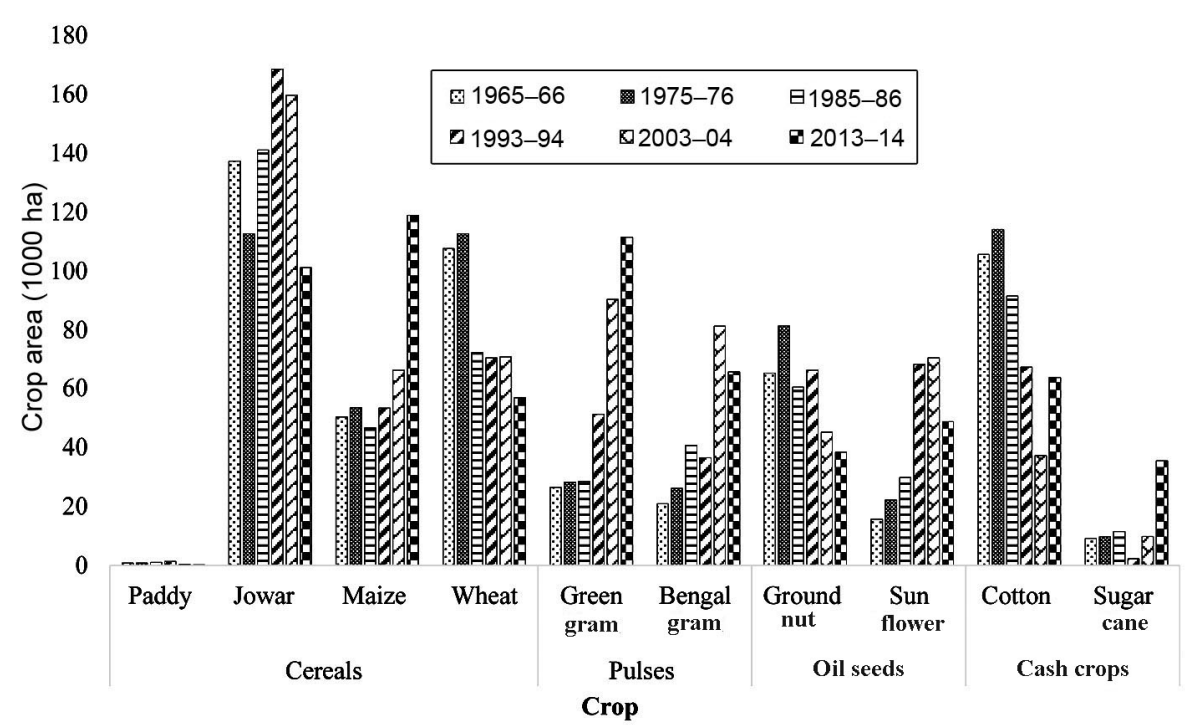

Figure 6. Cultivated area of major crops grown in the Malaprabha command area. (Source: Data compiled from refs 25 and 31 and district at a Glance reports of Bagalkot, Belgaum, Dharwad and Gadag, Government of Karnataka.)

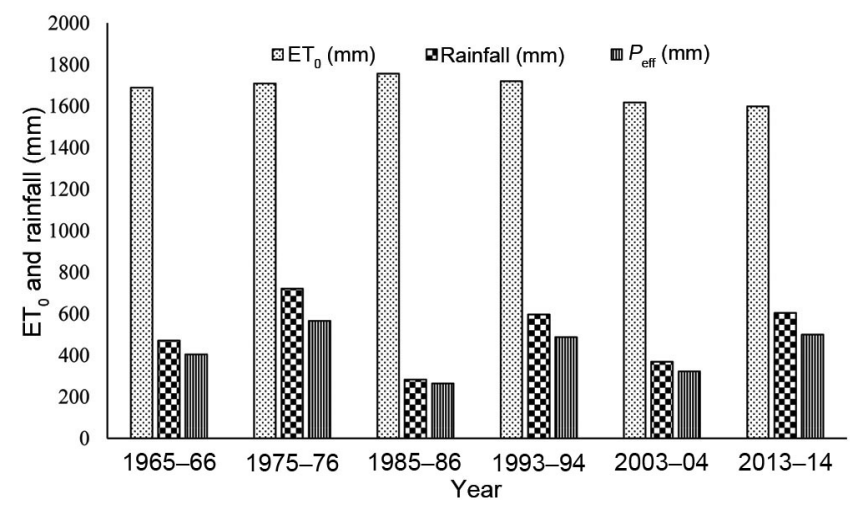

Figure 7. Reference evapotranspiration $\left(\mathrm{ET}_{0}\right)$, rainfall and effective rainfall $\left(P_{\text {eff }}\right)$ over Malaprabha command area.

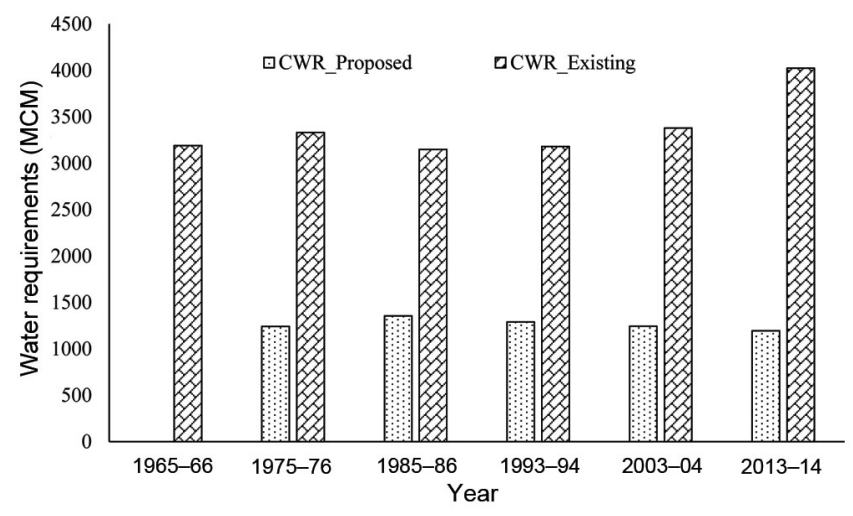

Figure 8. Crops water requirements for the proposed and existing cropping patterns in Malaprabha command area.

over the entire irrigable command area of 183,393 ha every decade, IWR works out to be higher in comparison to those for existing cropping patterns for the years 1975-

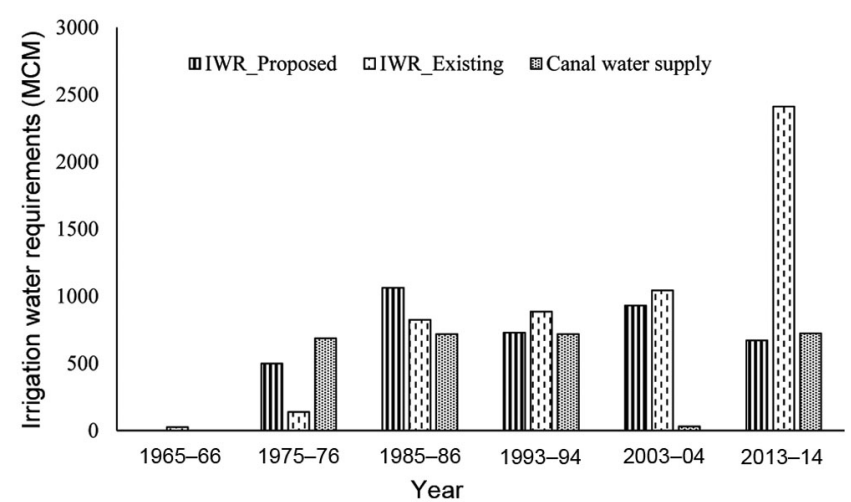

Figure 9. Irrigation water requirements for proposed and existing cropping-patterns and measured canal releases in the Malaprabha command area.

76 and 1985-86. Further, for the later years IWR for the existing cropping patterns was higher than that proposed, although the actual irrigated area was less than that proposed. This is due to cultivation of more waterintensive crops in the command area. The existing IWR soon after commissioning of the project was about $138 \mathrm{MCM}$, which increased to 824,884 and $1044 \mathrm{MCM}$ in 1985-86, 1993-94 and 2003-04 respectively. It is interesting to note that IWR for the recommended cropping pattern in the Malaprabha project proposal was 764.5 MCM (ref. 27), although, canal releases may vary depending on the storage in the reservoir. However, during 2013-14, the existing IWR increased significantly to 2410 MCM due to widespread adoption of more waterintensive crops.

Figure 9 also provides a comparison between IWR and canal releases for the period of analysis. During 1975-76, the release far exceeded the proposed and existing IWRs, 
validating the fact that excess water was supplied in the initial stages of the Malaprabha project and farmers who were provided with canal supplies for the first time over-irrigated their fields using flood-irrigation method. The situation improved during subsequent decades with releases being somewhat close to the proposed IWR for 1993-94. During 2003-04, the canal release was only 30.6 MCM, probably because it was a drought year with low storage levels in the reservoir. Consequently, the area under canal irrigation reduced in 2003-04 (Figure 3); the farmers turned to groundwater as an alternative source and area underground water irrigation increased significantly. During 2013-14, canal releases returned to normal levels but fell far short (233\%) of satisfying IWR for the changed cropping pattern.

Overall, it appears that since 2003-04 the Malaprabha project has not been able to achieve the demands imposed by farmers on account of the significant divergence between the objectives and existing situation on the ground in terms of the cropping pattern. While deficient rainfall and reduced reservoir inflows may have contributed to this situation, the more important factors appear to be a drastic change in cropping patterns favouring cash crops and expansion of irrigated agriculture with groundwater as the main source of water. The results of this study conform with the those of previous studies carried out for the same $25,28,30,31$. However, since the present analysis is based on data procured from a variety of independent sources, results and conclusions may have been influenced by inherent errors in the datasets, despite best efforts made to eliminate them. Also, assumption of a constant cropping pattern throughout the study period is a limitation of this study, but this aspect may not have influenced the results as much as changes in other variables. Future studies may incorporate finer resolution data on temporal and spatial variabilities in cropping patterns.

\section{Conclusion}

The analysis of the historical growth of irrigation in the Malaprabha command area revealed that commissioning of the irrigation project had a significant role in the development of irrigated agriculture in the region. From the spatio-temporal analysis of the growth of irrigated agriculture, it is evident that the contribution of canal supplies to irrigated agriculture was maximum until 1985-86 (61\%) and decreased thereafter. On the other hand, the contribution of groundwater to irrigation has increased since 1993-94. Also, regions close to the reservoir appear to be fully benefiting from canal water supplies, whereas regions located away from the reservoir seem to be benefiting from groundwater supplies. A shift from low water-consuming crops to water-intensive crops is observed and the area under cash crops has increased significantly. Canal releases not conforming to estimated
IWR and an increase in irrigation intensity (57\%) were observed in the study area at the end of 2013-14. Cropping-pattern violations, flood irrigation, illegal water withdrawals and poor maintenance of canal and associated structures are likely causes for the current status. The performance analysis shows that the Malaprabha irrigation project has not been able to enforce the planned objectives and goals. Results of this study depict the real status of irrigation development in the Malaprabha command area, highlighting the differences between project planning and farmer's aspirations. The quantitative information provided by this study will be useful in solving water-scarcity issues in the river basin through development of effective management strategies to improve the efficiency of the project and promote sustainable development of natural resources.

1. Gross Area Under Irrigation by Crops - All India. Statistical Year Book of India 2017, IRRIGATION Chapter, Table-12.2(A); http://mospi.nic.in/statistical-year-book-india/2017/181.

2. CWC, Reservoir level and storage. Bulletin dated 16 April 2015, Central Water Commission, 2015.

3. Dehghanisani, H., Oweis, T. and Qureshi, A. S., Agricultural water use and management in arid and semi-arid areas: current situation and measures for improvement. Ann. Arid. Zone, 2006, 45(3\&4), 355-378.

4. Shah, T., Past, present, and the future of canal irrigation in India India Infrastructure Report, Oxford University Press, 2011, pp. $70-87$.

5. Alcon, F., Garcia-Bastida, P. A., Soto-Garcia, M., MartinezAlvarez, V., Martin-Gorriz, B. and Baille, A., Explaining the performance of irrigation communities in a water-scarce region. Irrig. Sci., 2017, 35, 193-203.

6. Al Zayed, I. S., Elagib, N. A., Ribbe, L. and Heinrich, J., Spatiotemporal performance of large-scale Gezira irrigation scheme, Sudan. Agric. Syst., 2015, 133, 131-142.

7. Dejen, Z. A., Hydraulic and operational performance of irrigation schemes in view of water saving and sustainability: sugar estates and community managed schemes. Ethiopia. CRC Press, Balkema, Ethiopia, 2015.

8. Elshaikh, A. E., Jiao, X. and Hong Yang, S., Performance evaluation of irrigation projects: theories, methods, and techniques. Agric. Water Manage., 2018, 203, 87-96; https://doi.org/10.1016/ j.agwat.2018.02.034et.

9. Kuscu, H., Bölüktepe, F. E. and Demir, A. O., Performance assessment for irrigation water management: a case study in the Karacabey irrigation scheme in Turkey. Afr. J. Agric. Res., 2009, 4(2), 124-132.

10. Rani, S. Y. R., Venkateswarao, B. and Sreekanth, S., Modernization of an existing irrigation project by performance evaluation using performance indicators. Int. J. Math. Eng., 2011, 141, 12731292.

11. Singh, H. P., Sharma, M. R., Hassan, Q. and Ahsan, N., Performance evaluation of irrigation projects - a case study of lift irrigation scheme Sirsa Manjholi in Solan area of Shivalik Himalayas. Asian J. Adv. Basic Sci., 2013, 1(1), 79-86.

12. Bastiaanssen, W. G. M. and Bos, M. G., Irrigation performance indicators based on remotely sensed data: a review of literature. Irrig. Drain. Syst., 1999, 1225, 291-311; https://doi.org/10.1023/A.

13. Thiruvengadachari, S. and Sakthivadivel, R., Satellite remote sensing for assessment of irrigation system performance: a case study in India. IWMI Research Report 009, 1997; https://doi.org/ $\underline{10.3910 / 2009.017}$. 


\section{RESEARCH ARTICLES}

14. Srinivasulu, A., Crop water requirements in comparison to actual water applied in some canal commands of Krishna Western Delta. J. Agric. Eng., 2003, 40(4), 43-50.

15. Kadam, U. S., Performance assessment of heterogeneous irrigation schemes in India. Doctoral Thesis, Loughborough University, 2015; https://hdl.handle.net/2134/18589.

16. Chandran, K. M. and Ambili, G. K., Evaluation of minor irrigation schemes using performance indicators: case studies from South India. Sustain. Water Resour. Manage., 2016, 2(4), 431-437; https://doi.org/10.1007/s40899-016-0074-3.

17. Chandran, K. M., Joseph, E. J. and Sushanth, C. M., Performance evaluation of selected irrigation systems in Kerala state, India. Irrig. Drain., 2016, 65(5), 613-619; https://doi.org/10.1002/ird. 2012.

18. Chatterjee, S. K., Banerjee, S. and Bose, M., Climate change impact on crop water requirement in Ganga River. In Third International Conference on Biology, Environment and Chemistry (IPCBEE), IACSIT Press, Singapore, 2012, vol. 46.

19. Babu, R. G., Babu, G. R. and Kumar, H. V. H., Estimation of crop water requirement, effective rainfall and irrigation water requirement for vegetable crops using CROPWAT. Int. J. Agric. Eng., 2015, 8(1), 15-20.

20. Gangwar, A., Nayak, T., Singh, R. M. and Singh, A., Estimation of crop water requirement using CROPWAT 8.0 model for Bina Command, Madhya Pradesh. Indian J. Ecol., 2017, 44, 71-76.

21. Surendran, U., Sushanth, C. M., George, Mammen and Joseph, E. J., FAO-CROPWAT model-based estimation of crop water need and appraisal of water resources for sustainable water resource management: pilot study for Kollam district-humid tropical region of Kerala, India. Curr. Sci., 2017, 112, 76-86.

22. Trivedi, A., Pyasi, S. K. and Galkate, R. V., Estimation of evapotranspiration using CROPWAT 8.0 model for Shipra River Basin in Madhya Pradesh, India. Int. J. Curr. Microbiol. Appl. Sci., 2018, 7(5), 1248-1259.

23. Verma, R., Gangwar, A., Kumar, M. and Verma, R. K., Study on water requirement of rice using CROPWAT model for Lucknow Division of Uttar Pradesh. J. Agri. Search., 2019, 6(1), 44-49.

24. Allen, R. G., Pereira, L. A., Raes, D. and Smith, M., Crop evapotranspiration, guidelines for computing crop water requirements. FAO Irrigation and Drainage Paper 56, Food and Agriculture Organization, Rome, Italy, 1998, p. 293.

25. Madar, Y. M., Regional disparities in the agricultural development in Malaprabha command area. Doctoral thesis, Department of Geography, Karnataka University, Dharwad, 1993; http://hdl. handle.net/10603/107950.

26. Detailed project report of Malaprabha reservoir. Collected manually from MRBC, Division II, Office at Navilutheertha, Belgaum district, Karnataka, 2008, revised version.
27. Command Area Development Authority (CADA) report for Malaprabha and Ghataprabha river basins. Collected manually from CADA Office Belgaum, Karnataka, 2016.

28. Reshmi, T. V., Christiansen, A. B., Badiger, S. and Barton, D. N., Hydrology and water allocation in Malaprabha-Comprehensive database and integrated hydro economic model for selected water services in the Malaprabha river basin. NIVA-SNO Report 56952008, 2008.

29. Biswas, D. and Venkatachalam, L., Institutions and their interactions: an economic analysis of irrigation institutions in the Malaprabha dam project area, Karnataka, India. Working Paper 250, The Institute for Social and Economic Change, Bangalore, 2010, ISBN 978-81-7791-106-0.

30. Reshmidevi, T. V. and Nagesh Kumar, D., Modelling the impact of extensive irrigation on the groundwater resources. Hydrol. Process., 2014, 28(3), 628-639.

31. Chitragar, S. L., Regional imbalances in agricultural development of Malaprabha river basin: a geographical perspective. Doctoral thesis, Department of Geography, Karnataka University, Dharwad, 2018; http://hdl.handle.net/10603/201564.

32. Thrasher, B., Xiong, J., Wang, W., Melton, F., Michaelis, A. and Nemani, R., Downscaled climate projections suitable for resource management. Eos Trans. Am. Geophys. Union, 2013, 94, 321323.

33. Jain, S., Salunke, P., Mishra, S. K., Sahany, S. and Choudhary, N., Advantage of NEX-GDDP over CMIP5 and CORDEX data: Indian Summer. Atmos. Res., 2019, 228, 152-160.

34. Kumar, P., Kumar, S., Barat, A., Parth Sarthi, P. and Sinha, A. K., Evaluation of NASA's NEX-GDDP-simulated summer monsoon rainfall over homogeneous monsoon regions of India. Theor. Appl. Climatol., 2020, 141, 525-536.

35. Smith, M., CROPWAT: a computer program for irrigation planning and management. Food and Agriculture Organization, Rome, Italy, 1992.

36. Doorenbos, J. and Pruitt, W. O., Crop water requirements. FAO Irrigation and Drainage Paper No.24, Food and Agricultural Organization, Rome, Italy, 1977.

37. Doorenbos, J. and Kassam, A. H., Yield response to water. FAO Irrigation and Drainage Paper No. 33, Food and Agricultural Organization, Rome, Italy, 1979.

Received 6 March 2020; revised accepted 13 July 2020

doi: $10.18520 / \mathrm{cs} / \mathrm{v} 119 / \mathrm{i} 7 / 1149-1158$ 